\title{
Qualitative analysis of online communities to support international business decisions
}

DOI:

10.1007/978-3-642-39747-9_35

Link to publication record in Manchester Research Explorer

\section{Citation for published version (APA):}

Sinkovics, R. R., Penz, E., Molina-Castillo, F. J., \& Martínez-López, F. J. (Ed.) (2014). Qualitative analysis of online communities to support international business decisions. In Handbook of Strategic e-Business Management (pp. 841-862). (Progress in IS). Springer Nature. https://doi.org/10.1007/978-3-642-39747-9_35

\section{Published in:}

Handbook of Strategic e-Business Management

\section{Citing this paper}

Please note that where the full-text provided on Manchester Research Explorer is the Author Accepted Manuscript or Proof version this may differ from the final Published version. If citing, it is advised that you check and use the publisher's definitive version.

\section{General rights}

Copyright and moral rights for the publications made accessible in the Research Explorer are retained by the authors and/or other copyright owners and it is a condition of accessing publications that users recognise and abide by the legal requirements associated with these rights.

\section{Takedown policy}

If you believe that this document breaches copyright please refer to the University of Manchester's Takedown Procedures [http://man.ac.uk/04Y6Bo] or contact uml.scholarlycommunications@manchester.ac.uk providing relevant details, so we can investigate your claim.

\section{OPEN ACCESS}




\title{
Qualitative Analysis of Online Communities to Support International Business Decisions
}

\author{
Rudolf R. Sinkovics, Elfriede Penz \\ and Francisco Jose Molina-Castillo
}

\begin{abstract}
Social, cultural, political and technological forces have significantly transformed the competitive landscape of the global economy. Amongst these forces, technology has arguably had the most rejuvenating impact on the way international businesses interact with each other and their customer base. Endusers are making use of computer-mediated communications, newsgroups, chat rooms, email list servers, personal World Wide Web pages and other online formats at an unprecedented pace, and as they share ideas and obtain information about products and services, firms are extending their market research activities to these domains. These new tools, online communities, virtual communities and virtual worlds have emerged as a fascinating and useful pool of collective experience for international business. However, the utilization and analysis of this body of knowledge for international business decisions is still in its infancy. This paper analyzes the potential of these tools to inform international business decisions. We explain how to identify and access each of these communities, and how to convert the qualitative information available from online communities into a strategic input for the firm.
\end{abstract}

Keywords Communities - International business decisions - Qualitative research • Market research · Network innovation

\footnotetext{
R. R. Sinkovics $(\bowtie)$

The University of Manchester, Manchester Business School, Booth Street West, Manchester M15 6PB, UK

e-mail: Rudolf.Sinkovics@manchester.ac.uk

E. Penz

Vienna University of Economics and Business, Institute for International Marketing

Management, Augasse 2-6 A-1090 Vienna, Austria

e-mail: Elfriede.Penz@wu.ac.at

F. J. Molina-Castillo

University of Murcia, Campus de Espinardo 30100 Murcia, Spain

e-mail: fjmolina@um.es
} 


\section{Introduction and Motivation}

The capacity to innovate and the ability to respond to, if not shape, the competitive environment is key to sustained firm performance (Molina-Castillo et al. 2011). While the literature has produced extensive empirical accounts on how to facilitate and manage innovation within firms, an extension beyond firm boundaries, specifically to firm-customer relationships and networks, has not received so much attention (Evanschitzky et al. 2012). This is remarkable as functional integration of economic activities across a wider geographical space is dramatically increasing the number of economic actors participating in the quest for superior innovation performance. Lew and Sinkovics (2012, p. 247) produce an integrative innovation matrix along the dimensions "commercialization" and "source of technology deployment" leading to (a) closed innovation, drawing on a firm's internal resources, (b) inbound innovation, drawing on resources external to the firm, (c) inside-out innovation, whereby firms stimulate innovation via the provision of a network-level platform (such as the Google Android operating system) and (d) open network innovation, making use of resources external to a firm, offered by a community such as Linux open source.

This paper draws specific attention to cell (d) in their framework, termed 'open network innovation' because "networks of actors can benefit from the technology developments contributed by networks of actors (for example, volunteer communities or a business ecosystem)" (Lew and Sinkovics 2012, p. 248). This idea corresponds to suggestions from the network innovation literature, where the interaction between users when using a product reinforces the value of the product itself (Molina-Castillo et al. 2011). The argument in this paper is that value can be created through capturing and commercializing external resources available at the network level. New technologies provide extraordinary new tools for firm-customer interaction, relationship building, and information sharing, variously termed "online communities" (Jang et al. 2008), "virtual communities" (Blanchard 2008; Brodie 2009) or "virtual worlds" (Hendaoui et al. 2008). Computer-mediated information exchange between consumers is considered objective and reliable (Casaló et al. 2010), suggesting that the feedback about products and services offered via this channel may supersede traditional measures (Chen and Hung 2010).

The advent of networked computing is opening new opportunities for research and innovation in international business (IB) (Mandiberg 2012), consumer analysis (Nambisan and Watt 2011), new product decision making (Wu and Fang 2010), brand extension into the market (Song et al. 2010), the generation of brand relationships (Zhou et al. 2012) and, in turn, the evaluation of the potential value of communities (Spaulding 2010). This explains why there is an increasing interest in learning about communities (Wang 2010), and how to organize (Scarpi 2010) and manage them (Dholakia et al. 2004; Mahr and Lievens 2012).

Within this paper, a qualitative approach is pursued to analyze online communities and to demonstrate how the insights obtained from these communities can be used for IB decisions. This is in line with Marschan-Piekkari and Welch 
(2004), who suggest that qualitative methods are becoming increasingly important in IB research. It also builds on Sinkovics et al. (2005), who argue that qualitative methods help us to see what is behind all the numbers and thus cope with information overload, offer a toolset to understand the multilayered dimensions of globalization, and allow techniques to be tailored to the research problem rather than vice versa. Furthermore, the online community environment is still a relatively new phenomenon and despite some acclaims of the extraordinary use of online communities for interaction, committed exchange and relationship building (Ciaramitaro 2011; Kietzmann et al. 2011; Rheingold 1993), there are critical accounts pointing at the exaggerated value of online interaction for marketing communication and advertising (Clemons et al. 2007), meaningful interaction and connection (Turkle 2011) and successful firm internationalization (Yamin and Sinkovics 2006). Thus, a qualitative, exploratory approach in analyzing online communities is deemed appropriate to offer insights (Ghauri et al. 2009) about the value of online communities for IB decisions, while a structured approach to analyzing the data via computer assisted qualitative data analysis (CAQDAS) will help to enhance the trustworthiness of our findings and enable us to contribute to theory (Sinkovics and Alfoldi 2012; Sinkovics et al. 2008).

The paper is structured as follows. First, we provide some conceptual background on communities and motivate the research by pointing at the paucity of conceptual and empirical work on online communities in the IB literature. We then introduce social exchange theory to explain consumers'/individuals' motivations to contribute to the development of these communities and how it relates to network innovation literature. We then explore conceptually how various types of communities and interaction between users can help IB managers and decision makers, who may tap into the information generated. This information can support IB and management decisions. In the ensuing chapter, we offer an empirical example that demonstrates how the qualitative, text-based information available in online communities can be analyzed by means of computer-assisted qualitative data analysis (CAQDAS) and how the findings can support marketing decisions. We conclude by outlining the limitations of this study and providing implications for future work.

\section{Conceptual Background}

\subsection{Online Communities and the Changing Landscape of IB}

The management literature is unambiguously firm in its assessment that the collective power of online communities is shaking up existing industries (Hof 2005). Various forms of sharing, facilitated by information and communication technologies (ICTs), are likely to change the status quo in a number of sectors. For instance, the telecom sector has experienced dramatic competitive pressure, with 
more than 100 million people now using Skype software to share processing power and bandwidth and call each other for free over the internet. In a similar vein, the entertainment, and specifically the music and video, industry has experienced challenges due to the sharing of proprietary assets over online networks. Similar disruptions and changes are taking place in the software, retail, finance, media and advertising industries. As online networks are becoming the locus of innovation, firms are becoming more porous and decentralized (Hof 2005).

Despite this significant, technology-induced shift, the academic IB literature has been relatively slow to provide conceptual and empirical contributions regarding online communities and their ramifications for the IB agenda. ICTs, more broadly speaking, have indeed been discussed, for example regarding the economic geography of business in the internet age (Leamer and Storper 2001) or the potential impacts of ICT advances on IB theory (de la Torre and Moxon 2001). However, research on the specific implications of online communities for IB issues has so far been confined to functional disciplinary journals devoted to marketing, consumer behavior, information systems or the channels literature (e.g. Bagozzi and Dholakia 2006; Brown et al. 2007; Kozinets 2002; Scarpi 2010).

Kogut and Zander (1993), in their seminal piece on the knowledge of the firm and the evolutionary theory of the multinational enterprise (MNE), suggest that firms are 'social communities' that specialize in the creation and internal transfer of knowledge. Yet, the key focus of their analysis is the internal community perspective. In this paper, we decidedly extend the perspective beyond the firm to the network and examine resource externalization (Lew and Sinkovics 2012, 2013) via open online communities and the implications for innovation at the network level. We examine in how far online communities can create value for firms to support IB decisions, specifically enhance innovation generation and support internationalization decisions.

\subsection{The Nature of Online Communities}

Online communities are 'social aggregations' that emerge from the Net when enough people carry on those public discussions long enough, with sufficient human feeling, to form webs of personal relationships in cyberspace (Rheingold 1993). With literature on online communities emerging from the consumer behavior literature (Nambisan and Watt 2011), the marketing literature (Mandiberg 2012) and the information systems/ICT literature (Kim et al. 2011), a unified definition is not yet available. Muniz and O'Guinn (2001) suggest that online communities often involve consumers attempting to inform and influence fellow consumers about products and brands. Kollock and Smith (1999) simply argue that an online community is a social network that uses computer support as the basis of communication. Others highlight the relational dimension of online communities (Chan and Li 2010). Preece (2000) suggests that online communities are made up of people who interact socially to satisfy their own needs or to perform special roles with a shared purpose, and whose interaction is guided by tacit and explicit policies, with 
computer systems supporting and mediating the interaction. In a more academic conceptualization, Andrews et al. (2002) posit that a community is not a physical place but a set of social relationships. They suggest that, although the members of a demographic group may share common interests, needs and goals, they do not necessarily comprise a community unless the group establishes a network of social relationships. These relationships are now achieved online, in virtual spaces created through a combination of communication and content developed by community members (Jang et al. 2008). This can include the sharing of goals and ideas, with no constraints on geographical location or ethnic origin (Hsu and Lu 2007). The objective, as Sun et al. (2012) point out, is to achieve sustained participation in these communities.

Kozinets (1999) defines online communities from a marketing and management perspective as networks of people whose online interactions are based upon a shared enthusiasm for, and knowledge of, a specific consumption activity or related group of activities. Online communities differ from face-to-face communities in that there is a lack of real-world physical cues, and members have the ability to change their identity, social status, and purpose. Brown et al. (2007) demonstrate that the flow of information between participants in online networks may be different in nature to that in an offline context. Online communities can be supported by a variety of internet technologies, including Usenet newsgroups, list servers, bulletin board systems, and websites.

According to Armstrong and Hagel (1996), communities can be classified based on transaction, interest, fantasy and relationship types. Winkler and Mandl (2004) differentiate between asynchronic and synchronic computer-mediated communication, where asynchronic formats includes web forums, newsgroups and mailing lists, while synchronic formats include chats and multi-user dungeons (MUDs). Within the empirical section of this paper, the massively multiplayer online roleplaying game (MMORPG) World of Warcroft (WoW) will be used. This is a synchronic form of online community, as multiple players interact at the same time and certain interaction modes, such as 'whispers', allow players to interact in real time.

Recent work has analyzed whether the size of the community is important and has concluded that the members of small communities develop greater community loyalty (Scarpi 2010). Other work has considered the positive and negative effects that could arise from communities. For example, community interaction is considered an important dimension when engaging with customers and there are suggestions that a lack of e-service support may lead to harmful effects for firms (Tsai and Pai 2012). In terms of communities that are relevant for IB, Sinkovics et al. (2009) provide a graphical representation of online communities along two dimensions, commercial/social value and the nature of the exchange (creative, playful or functional). Their examples include Facebook, LinkedIn, Moodle and WOW, the last of which is a 'virtual world' online community (Gardiner and Ritchie 1999), that is, a simulated environment that reflects the real world very closely in that it includes representations such as people, landscape or other objects (Kock 2008). 


\subsection{Social Exchange and Network Innovation}

Social exchange theory is fundamental to understanding behavior between individuals and within groups. It explains why people help each other, and why there is information exchange and support between group members (Cropanzano and Mitchell 2005). The theory demands that virtual interaction has to be rewarding for both producer and participant ( Anderson et al. 1999; Emerson 1976). This reward is essential because, as Wasko and Faraj (2005) point out, consumers spend time and effort in community environments with no immediate benefits for the contributors. While there is increasing research on social exchange processes in virtual communities (Hemetsberger 2002) and the 'open' dimension of innovation and exchange (von Hippel and von Krogh 2003), there are still many unanswered questions regarding the value propositions for community users and the attraction for visitors (Gu et al. 2007).

Social exchange theory has considerable theoretical value for the analysis of innovative user behavior in an online community context. Andrews et al. (2002) provide a framework for demographic groups that are resistant to online community interaction. They suggest that good sociability creates an online culture where people feel comfortable interacting and their expectations are met.

Kozinets (2002) comments that participants in online communities are often engaged in informing and influencing fellow consumers about products, brands or organizations. This knowledge-sharing process is critical to understanding why and how individuals choose to exchange knowledge with other community members (Chen and Hung 2010) and could imply a very important source of knowledge creation for innovation (Mahr and Lievens 2012). Customers and consumers rarely innovate in isolation; they do so in cooperation with like-minded people. Acquaintances, colleagues and friends contribute know-how and offer the active support necessary for transforming ideas into products (Füller et al. 2007). Füller et al. (2006) develop a community-based innovation method to access online communities, and identify how firms might interact with community members to obtain valuable input for new product development. The idea behind this approach is how to co-create value between partners in order to obtain a product that better fits customers' demands and has high chance of profitability (Perks et al. 2012). They suggest that, in order to utilize the full innovative potential of consumers for virtual design, communities should provide a stimulating environment that enriches consumers' creativity and offers functionality that helps participants to work jointly on a problem. Thus, understanding consumer-toconsumer interaction is critical to analyzing the behavioral intentions of these customers and how the communities influence them (Chan and Li 2010). Furthermore, communities may help to identify the needs and desires of particular individuals or groups of people (Casaló et al. 2008), and rapidly disseminate knowledge and perceptions regarding new products (Dholakia et al. 2004).

Despite these attractive features of communities, to date community members have rarely been included in firms' core value creation and new product 
development processes. The use of communities has so far been limited to somewhat typical market research activities (Füller et al. 2006). Balasubramanian and Mahajan (2001) discuss various perspectives on the role and implications of virtual communities and their economic leverage. Füller et al. (2006) suggest that, with new developments such as the 'toolkit approach', customers might even be able to develop their own new products. This perspective is essentially aligned with the open network innovation approach, which extends beyond the traditional IB focus of the firm, as conceptualized by Lew and Sinkovics (2012).

Social exchange theory is closely linked to the network innovation economic literature. In a business to business context, inter-organisational innovation happens when firms learn from other firms they are related by "producing sets of interorganisational experiential rules that are partly separate from the rules of each of its members. Thus, the inter-organisational collaboration is in itself stressed as a unique learning entity" (Holmqvist 2004). Inter-organisational exploration consists on the firm's use of explorative knowledge that proceeds from, or is developed in the setting of, its business relationships with the main purpose of obtaining a better product. In a consumer to consumer context, this network innovation is operationalized with the term network externalities. As the economy becomes more interconnected, more products exhibit network externalities (Srinivasan et al. 2004). Therefore, in these markets the utility of a product depends not only on its attributes, but also on the number of consumers who have adopted the product ant the network of users created around them. These users co-create value with its mere interaction which can even override the benefits of the product itself. Direct network effects occur when the value of a good to any user is an increasing function of the network's size (Farrell and Saloner 1985). The effect is simply generated from the growing number of users adopting the same product. Direct network effects are also called demand-side economies of scale (Katz and Shapiro 1986) or economies of mass adoption (Norsworthy and Lee 1998). In a business to consumer context, this network innovation arises when indirect network externalities exist. Indirect network effects occur when the introduction of complementary goods by a firm increases as the sales of the primary good increases (Lee and O'Connor 2003). Therefore, firms will be motivated to launch more products related to this network of products in order to increase the value perceived by customers (Basu et al. 2003).

\subsection{Qualitative Methods for the Analysis of Online Communities}

In terms of research methods, a number of options exist for the analysis of online communities. These can be seen as complementary to other methods used to study market research on the internet.

Online Delphi: The aim of the online Delphi method is to generate reliable and relevant information about issues where only incomplete knowledge is available. 
The method is used to ascertain future trends or developments in specific markets, or to assess the potential of firm innovations (Okoli and Pawlowski 2004). An online Delphi usually extends over a couple of months and participants are usually required to respond twice. The method is rather similar to the use of panels, in that it encompasses the same topics, but it is more limited in terms of its duration (Rowe and Wright 1999).

Netnography: Netnography is fundamentally based on the principles of ethnography, whereby group behavior and the individual behavior of group members is actively researched via the group participation of the researcher (Hitzler 2007). In the internet context, the unit of analysis is the conversation or social interaction exhibited by group members. Members of online communities can thus be analyzed with respect to their thinking about specific topics, how they assess various products or brands, and which specific threads of communication emerge via community interaction (Beckmann and Langer 2007). Kozinets (1999) introduced a four-step netnography method: (1) accessing a community (cultural entrée), (2) collection and analysis of data, (3) interpretation of data, and (4) consideration of ethical dimensions. ${ }^{1}$

Analysis of textual data: There are a number of conceptual papers and methodological contributions that suggest processes that can be used to generate insights from textual data, specifically those derived from expert interviews (Kuckartz 2007; Sinkovics et al. 2008). Sinkovics et al. (2008) suggest adhering to specific operational standards in the application of the research process and the analysis of the qualitative data, in order to overcome criticisms about the trustworthiness of qualitative data analysis and the underlying data structures (Guba and Lincoln 1989). As online communities offer a plethora of codified textual data, CAQDAS is ideally suited to help the process, improve the efficiency of the research process, and augment inter-rater reliability and the generalizability of the data (Penz et al. 2005; Sinkovics and Alfoldi 2012; Sinkovics et al. 2008).

\section{Methodology}

To investigate the contribution that the analysis of online communities can make to support IB decisions, such as innovation generation from a network perspective and market entry and development, we draw on netnography (Kozinets 2002). Text-based material is analyzed following some of the guiding principles of grounded theory (Strauss and Corbin 1994; Strauss and Corbin 1998). Both netnography and grounded theory require close interaction between researcher and the underlying qualitative text-material, and lead to an iterative process in coding

\footnotetext{
${ }^{1}$ Netnography is different from (social) network analysis. The latter is fundamentally a quantitative analysis, which uses nodes and edges to gauge the strengths of connections between individual members of a group as well as determine the structure of the net (Carrington et al. 2005; Wasserman and Faust 1994).
} 
and analysis. Through continuous development and re-negotiation of insights from theory and interview data, trustworthiness, and transparency of the process and its findings are enhanced (Sinkovics and Alfoldi 2012).

Online gaming has become extremely popular of late and is overtaking the PC and console gaming market. Research estimates that the revenue from online gaming will be $\$ 25.3 \mathrm{bn}$ in 2014. Drivers for growth are high-speed broadband connections, increasing internet penetration, and the growing popularity of social networking sites. Europe, the Middle East and Africa (EMEA) accounted for about $37 \%$ of global revenues in 2009 but its share is expected to decline in 2014. Asia-Pacific, on the contrary, shows fast growth, with China the largest market, accounting for about 51 percent of this region's revenues in 2009 (Business Insights 2011).

The key research questions that inform the empirical explorations are as follows: (a) What is the value that companies are able to attach to the analysis of data from online communities, specifically online discussion boards and community forums? (b) What knowledge can be retrieved from MMORPG forum discussions? (c) How can online community information be used to provide continuous interaction between developers and users, and thus act as a basis for the establishment of relationships and open network innovation? The research questions are examined from a cross-cultural perspective taking cultural (e.g., values, norms) and social (e.g., norms, exchange) characteristics of online communities into account. This allows covering IB relevant diversity of community activities. In particular, German and Chinese forum discussions are selected because it is assumed that cultural and social diversity is large between these groups. In addition, Germanand Chinese-speaking communities differ with regard to factors such as prevalence of online communities and diffusion of technology.

There are a number of official forums of MMORPGs and these are usually linked to the developer's website and hosted by the company. Game developers provide web forums to facilitate interaction between users. In addition, private users or groups often start forum discussions themselves with like-minded users. In general, web forums are usually organized along thematic threads that are gamespecific. In addition, these forums include areas where off-topic matters can be discussed. Only registered users can post comments; however, anyone may search the discussions and read the comments (Kozinets 1999; Kozinets 2002).

In our study, the German and Chinese-speaking web forums are selected on the basis of the popularity of the games discussed. First, the empirical research focuses on one of the most popular MMORPGs worldwide, WoW (developed by Blizzard Entertainment), and investigates text-based information from German and Chinese users of the respective WoW online communities. In addition, two games with German-speaking and Chinese-speaking communities, respectively, were selected to account for culture-specific idiosyncrasies. These are EVE Online (Germanspeaking, developed by CCP Games, Iceland) and Perfect World (Chinesespeaking, developed by Beijing Perfect Word). Other selection criteria for these games were the types of topics discussed in their web forums, the number of posts, the availability of the games and access to the web forums (See Tables 1 and 2). 
Table 1 Selected threads in German and Chinese-speaking communities on the topic "motivation to play MMORPGs"

\begin{tabular}{|c|c|c|c|}
\hline German-speaking communities & Threads & Answers & Hits \\
\hline \multicolumn{4}{|l|}{ World of Warcraft } \\
\hline Official German-speaking forum & Motivation? & 20 & 1,473 \\
\hline \multirow{3}{*}{$\begin{array}{l}\text { German World of Warcraft website } \\
\text { inWoW.de }\end{array}$} & Why do you play WOW? & 159 & 4,616 \\
\hline & What motivates you? & 62 & 2,174 \\
\hline & Motivation? & 44 & 1,862 \\
\hline \multicolumn{4}{|l|}{ EVE online } \\
\hline Fansite EVE Germany & EVE is fun, because.... & 44 & 1,957 \\
\hline \multicolumn{4}{|l|}{ Chinese-speaking communities } \\
\hline \multicolumn{4}{|l|}{ World of Warcraft } \\
\hline Official Chinese-speaking Forum & $\begin{array}{l}\text { Is there any better game in the world } \\
\text { than WOW? }\end{array}$ & 19 & 729 \\
\hline \multirow[t]{2}{*}{17173 WoW Forum } & $\begin{array}{l}\text { When playing this game I feel very } \\
\text { happy }\end{array}$ & 48 & 440 \\
\hline & $\begin{array}{l}\text { Shall I give up The legend of Mir for } \\
\text { WoW }\end{array}$ & 46 & 394 \\
\hline \multicolumn{4}{|l|}{ Perfect World } \\
\hline Official Chinese-speaking forum & Why do you play Perfect World? & 131 & 3,434 \\
\hline \multirow[t]{5}{*}{ Unofficial forum Gamebase } & $\begin{array}{l}\text { What are the reasons to continue playing } \\
\text { WoW? }\end{array}$ & 16 & 887 \\
\hline & $\begin{array}{l}\text { One question, how do you like Perfect } \\
\text { World? }\end{array}$ & 16 & 1,436 \\
\hline & Perfect World is my No 1 & 17 & 3,598 \\
\hline & $\begin{array}{l}\text { What is the main reason for playing } \\
\text { Perfect World? }\end{array}$ & 82 & 733 \\
\hline & $\begin{array}{l}\text { What about the game attracts female } \\
\text { players? }\end{array}$ & 85 & 3,746 \\
\hline
\end{tabular}

Note "Answers" refers to the number of replies from other users in the same forum, "Hits" indicates the number of times the respective thread has been viewed

In WoW, ${ }^{2}$ players choose between two factions, "horde" and "alliance", that have specific races and characters who fight against each other. Blizzard offers hotselling extensions to the WoW game, which allows them to retain interest among existing players. In EVE Online, ${ }^{3}$ players primarily fight and trade in cyberspace. In this MMORPG, many users can play simultaneously. In December 2007 approximately 41,000 players were online simultaneously, setting a new record for this kind of game. Perfect World ${ }^{4}$ is an online fantasy role-playing game based on traditional Chinese myths. Although developed as a Chinese online game, an international version is now available through overseas licensing. Similarly to in

\footnotetext{
${ }^{2}$ WoW had a paid subscriber base of 12.1 million at the end of 2010 and holds more than $60 \%$ of the global MMORPG market (2011).

3 EVE Online had 200,000 subscribers by the end of 2010 (Business Insights 2011).

4 Perfect World uses a 'freemium' business model, which means that use of the game is free but users are charged for items within the game.
} 
Table 2 Selected threads in German and Chinese-speaking communities on the topic "critiques of MMORPGs"

\begin{tabular}{|c|c|c|c|}
\hline German-speaking communities & Threads & Answers & Hits \\
\hline \multicolumn{4}{|l|}{ World of Warcraft } \\
\hline Official German-speaking forum & Better graphics, please... & 105 & 2,159 \\
\hline \multirow{2}{*}{$\begin{array}{l}\text { German-speaking community } \\
\text { wow.gamona.de }\end{array}$} & Play classical quests? Sheer impossible... & 36 & 2,893 \\
\hline & Is it old hat? & 49 & 3,579 \\
\hline \multirow{3}{*}{$\begin{array}{l}\text { German World of Warcraft page } \\
\text { inWoW.de }\end{array}$} & Now I am caught, too & 72 & 6,453 \\
\hline & Return of the lags! & 48 & 1,886 \\
\hline & The most silly answers by $<\mathrm{GM}>$ 's & 28 & 2,974 \\
\hline \multicolumn{4}{|l|}{ EVE Online } \\
\hline \multirow[t]{2}{*}{ Fansite EVE Germany } & What annoys you most about EVE? & 86 & 4,436 \\
\hline & EVE only bores me... & 491 & 22,789 \\
\hline \multicolumn{4}{|l|}{ Chinese-speaking Communities } \\
\hline \multicolumn{4}{|l|}{ World of Warcraft } \\
\hline Official Chinese-speaking forum & $\begin{array}{l}\text { We request vehemently the people at } \\
\text { The } 9 \text { to work long hours so that the } \\
\text { servers are running again before } \\
8 \mathrm{pm} \text { ! }\end{array}$ & 62 & 2,442 \\
\hline $17173 \mathrm{WoW}$ Forum & $\begin{array}{l}\text { We request that The } 9 \text { amend the } \\
\text { maintenance time for servers }\end{array}$ & 13 & 338 \\
\hline \multicolumn{4}{|l|}{ Perfect World } \\
\hline Official Chinese-speaking forum & $\begin{array}{l}\text { You easily get bored at Level 100. I have } \\
\text { just noticed a big flaw in Perfect } \\
\text { World. }\end{array}$ & 85 & 3,161 \\
\hline \multirow[t]{3}{*}{ Inofficial forum Gamebase } & $\begin{array}{l}\text { Too many tasks in the game, one simply } \\
\text { cannot comply with them. }\end{array}$ & 60 & 5,840 \\
\hline & $\begin{array}{l}\text { Maintenance at } 2: 30 \text { without prior } \\
\text { notification } \ldots \text { protest }\end{array}$ & 18 & 3,376 \\
\hline & $\begin{array}{l}\text { The game is so boring. What do you } \\
\text { think? }\end{array}$ & 24 & 2,030 \\
\hline
\end{tabular}

Note "Answers" refers to the number of replies from other users in the same forum. "Hits" indicates the number of times the respective thread has been viewed

WoW, there are different races and tasks involved. Players can build their avatars using a wide variety of features, making the game very exciting graphically. Overall, the three MMORPGs selected for this research have similar structures and the games are organized similarly but they differ in content (trading versus fighting) and design (2D versus 3D). This makes them suitable for a cross-cultural comparison of web forum discussions.

To start the data collection process, the research team discussed the selection of topics (threads). Two major topics were chosen in order to support the research questions: (1) motivation for online gaming and (2) critiques of the games. This selection of threads is critical to the ensuing analysis. Some web forums do not offer a search function, and where searches are available they do not always return adequate results. Therefore, the threads were screened manually for evidence of 
content referring to 'motivation' or 'critique'. Some of the thread titles were not useful either because they did not match the contents.

Over a period of one month, two research assistants scouted for relevant topics within the web forums which could provide useful input for IB decisions. The digital text from the web forums was imported into the CAQDAS tool NVivo for further organization and subsequent analysis. NVivo (Richards 2005) allows text to be coded and a node system can then be derived based on the coding. This procedure formed the basis for further analytical queries and searches for evidence in the data corpus. Coding was done iteratively: First a rough node system was developed based on the structure of the threads. Later, the coding was refined following the grounded theory techniques of axial and selective coding.

\subsection{Findings: Motivation and Critiques}

The main two topics of interest for both language groups are (a) 'motivation to play online' and (b) 'critiques of games'. Motivation is subdivided into 16 categories (subnodes), and critique into 14 . We found that the users tended to have similar motivations for playing and tended to criticize certain common aspects of the games.

In order to answer the research questions, matrix coding and coding queries were run using NVivo. The selected attributes (game: WoW, EVE Online, Perfect World; language-group: German, Chinese) were combined with selected nodes. The result was a list of references, referring to statements made by users in the online communities. These statements could be either single words or sentences reflecting the respective nodes. Frequencies should be interpreted with caution though because they do depend on the wordiness of expressions in different languages, as well as on the number of threads selected on the topic in question. However, they provide a useful starting point for examining the users' statements in more detail and theorizing about patterns and relationships.

In the following, the results are discussed in relation to various themes that emerged. These themes can be divided into firm/developer-related versus userbased (or individual) and are discussed along the cross-cultural dimension. In the case of the firm/developer-related aspects, technical and business-model-related themes appeared. Insights from this kind of feedback can be transferred into product and service development within firms. Regarding their individual situation, the users stressed mainly psychological and social subjects and provide evidence for social exchange processes. As illustrated in Table 3, relationship management is critical for products such as MMORPGs. Users' perceptions of the game, both firm-related and user-related aspects, are expressed in online communities.

There are differences in the number of contributions to each topic coming from each game and from the German-speaking and Chinese-speaking forums. 
Table 3 Overview of results

\begin{tabular}{lll}
\hline & Technical & Business model \\
\hline Psychological & $\begin{array}{l}\text { E.g., good design/graphics } \\
\text { allows user to escape from } \\
\text { real world }\end{array}$ & $\begin{array}{l}\text { E.g., avoiding addiction through } \\
\text { subscription versus item-based } \\
\text { Social }\end{array}$ \\
& $\begin{array}{l}\text { E.g., meeting, connecting to others } \\
\text { (virtually), peer to peer mode, } \\
\text { translating the physical into } \\
\text { a virtual world }\end{array}$ & $\begin{array}{c}\text { E.g., 'freemium' models for users who } \\
\text { cannot afford expensive prices } \\
(\rightarrow \text { emerging markets) }\end{array}$ \\
& & \\
\hline
\end{tabular}

\subsection{Firm-Related Aspects Related to Motivation to Play and Criticism of MMORPGs}

The firm/developer-related issues mainly consisted of technical questions and comments, including for instance support, maintenance, connectivity, updates, the graphical interface and the performance of the game. Looking at users' opinions provides firms with decisive information about what features of a game should be kept, and contributes to product innovation and development. It also helps to identify areas where more support and a greater company presence is required, or with regard to cross-cultural idiosyncrasies, actions need to be adjusted to the respective context. Taking the exchange of information at this network level into account, international businesses can benefit from knowledge generated externally.

Technical aspects were more often discussed in the Chinese forums as motivating online game playing. Chinese users particularly stressed the design and graphical features of the games. In particular, Perfect World's 3D graphics were found to intrigue the Chinese-speaking users. This is not surprising since Perfect World (the Chinese game) is particularly known for its good graphics and therefore the positive sides of it tend to be brought up in forum discussions. In the official forum for WoW too, design is discussed as a driver of pleasure (e.g. "the environment, the atmosphere, each tree, how characters are looking, the movements-who knows of a game [whose] graphic is more beautiful than WOW?"). The way the virtual characters (avatars) can be designed appears to be one of the most fascinating aspects of MMORPGs for Chinese-speaking users.

For the German-speaking forums, graphical issues related to hardware and outdated graphics were issues that came in for criticism. Among the other technical issues raised by both language groups were connectivity and login problems; maintenance was perceived to take too long, was unexpected, and happened too often or at the wrong time. Support was criticized; bad customer service was mentioned in terms of both quality and speed. The latter issues were particularly common among Chinese WoW forum members and targeted the Chinese WoW support firm, 'The9'. For the Chinese users, the main critique in terms of content updates was the lack of new features, while the Germans also referred to new content but also commented that improvements in general were lacking. In criticizing content, the Chinese players argued that the number of open missions was 
limited, the game concept was bad, the game was one-sided, the virtual world was too small, the game itself was poor, there were too many tasks and levels in the game, and that there were not enough tasks. Chinese users also compared different games a lot, typically expressing the view that Chinese games were worse than or copied from other games.

A more business-focused topic relates to how users evaluate games based on cost. Perfect World, as an item-based MMORPG, seems to be preferred because it is free to use it, and the user only has to pay if he/she purchases game-related items or services. The advantage of this cost model is referred to in online web forums as a motivation for keeping on playing. However, mainly German-speaking users discussed the issue of 'becoming addicted' in the forums for the subscriptionbased games, especially WoW. This issue clearly has a psychological nature (for more details on this, see the next section). However, it also has a business model side. For example, users talked about trying to stop playing WoW but failing to do so. In response, fellow users suggested cancelling their account for a while. These examples illustrate that the chosen business model (subscription versus itembased) might have both psychological and financial influences on users.

Finally, some of the comments referred to the celebrities (e.g., supermodel Lin Chi Ling in Perfect World) who promote these games by creating characters for themselves and offer celebrity endorsement. The Chinese-speaking users appear to be very susceptible to this kind of advertising based on their postings in the forums. This form of endorsement motivates them to play the MMORPGs and encourages purchasing of the advertised products. However, this does not seem to be the case for WoW. The company invested in advertising using celebrities (e.g. Jean-Claude van Damme) but no mention by users of the game of this was found in the online web forums. As in the physical world, the selection of appropriate celebrities within specific target segments is key. Advertising-based business models are viable options for MMORPGs and this may lead to the development of alternative, cheap games for certain user segments.

\subsection{Individual Aspects of Motivation for Playing and Criticisms of MMORPGs}

Individual comments included psychological and social aspects and reveal social exchange processes within culturally diverse communities. With regard to intrinsic motivation, the Chinese players produced more comments than the German players. In both cases, users referred to escaping to a different world. The Chinese users elaborated on this by commenting that they could live out their fantasies, travel through fantasy worlds and that they enjoyed the environments created. In the Chinese forums, the users commented that they liked the idea of being someone else and being able to create new characters. For many, the games and the characters they create stir up emotions that remind them of actual people, 
events and feelings from their past. The German-speaking users, on the other hand, suggested that the games could be improved if the users could act as developers, creating designs and atmosphere. This would increase their feeling of escaping from the real world. While Chinese-speaking community members stress hedonic, socially compatible forms of exchange, German-speaking community members emphasize creative innovation and collaboration.

Both language groups argued that the games are entertaining, easy to play, full of music, sounds, animation etc., and they like the contents of the games. The users generally also seem to like killing monsters and avatars, in other words their ludic drive needs to be satisfied and the games help with this. Especially in the Germanspeaking forums and with regard to WoW, the players often stressed the fun factor in achieving something or leveling up. They generally argued that these games are relaxing, and offer a somewhat habitual way of spending time, but they also mentioned dependence and constraints, that they had invested a lot of time and money already and want to experience more with these games. This corresponds to the discussion above on the addictive potential of (subscription-based) MMORPGs. Feedback from users with similar problems seems to be found useful and thus these online forums seem to provide an additional benefit to the users, in that real-life problems can be discussed on them.

A major psychological issue with MMORPGs is a lack of fun when playing the game, leading to "boredom", which was one of the most common critiques in the forum discussions we studied. Boredom was cited as a critical factor in quitting playing by (Chinese) Perfect World users. The main arguments were that it is too repetitive and tasks not challenging enough. Some users commented that their friends had quit playing the game and that this had also had an impact on their decision. Thus, there are social factors at play here as well. The Chinese users felt that reaching the next level was laborious and the tasks were repetitive. They argued that friends and many other players had quit the game, that there was no help from others in the game and that the game had therefore become boring. German users, on the other hand, mentioned that it was difficult to connect to other players. This issue has two sides: first, as a negative consequence, users look for more interactive games; second, there may be a call for more single-user-focused games.

For the German-speaking users, fun was cited most often as a motivation for playing. Among Chinese-speaking users, however, interacting with other players and designing avatars individually were deemed important. Regarding interacting with others, for the German users an important feature of MMORPGs seems to be building up communities ('guild' within the MMORPG). The Chinese users, especially those posting about Perfect World, mentioned meeting like-minded people, helping other players, being part of a community with friends and colleagues, and even flirting and finding a husband or wife. Perfect World allows virtual kissing and hugging, which illustrates how the technical features of a game can have an important impact on users' motivation to play. For instance, (Chinese) users reported that playing MMORPGs offered topics of conversation for married couples. Thus, virtual communities are translated into the physical world and vice 
versa. In Perfect World, getting married is part of the game and is a clear attraction for users. This difference between the German- and Chinese-speaking users can be explained by cultural dynamics; while in the German-speaking world collaborating and having a good work ethic is valued, in China online dating has become increasingly popular.

\subsection{Qualitative Findings that Support International Business Decisions}

The analysis of qualitative data extracted from online communities reveals a number of potentially useful insights that can help support international business decisions. First, the computer-mediated information exchange between users of MMORPGs indeed offers insights about products and services that can be used for product enhancement and modification. As outlined in the motivation and critiques section, a number of different motivations to play online were identified which, when split along German and Chinese language-groups, reveals focal points that the firms need to address in making product/feature improvements for specific markets. For instance, in a Chinese setting, appealing graphical design as well as novel ways of interacting with other (virtual or real) people is important. In a German-speaking context, collaborative options and challenging new tasks are key to keep customers happy.

Second, firms can obtain value from the qualitative analysis of the communities when focusing on firm-related aspects. Users offered ample of information about features of the game, which can be considered absolute necessity for entertainment and enjoyment, while offering firms the opportunity to make business-model decisions in terms of pricing and functional/graphical aspects of the MMORPG virtual environment. As far as hardware related graphical issues are concerned, the information from the online community allows for market-selection and marketexpansion related decisions, as different hardware requirements in the crosscountry setting suggest different segmentation and targeting propositions.

\section{Conclusion}

Online communities and networks are a fascinating phenomenon that makes firms, as loci of innovation, more porous and indeed more decentralized (Hof 2005). Although it has been suggested that this collective power is shaking up the status quo in many industries, IB is challenged to explain the community phenomenon and its implications. In this paper, we examine how the extension of the innovation perspective beyond firm boundaries, towards the network level, can help us to understand firms' approaches to innovation generation and their attempts to draw on external resources (Lew and Sinkovics 2012). 
We explore the idea that value can be created through capturing and commercializing information resources that are available online, at the network level, in communities. Online communities, in this study, consist of users' opinions on product and service-related issues surrounding MMORPGs. The information is organized in threads and can be accessed and processed by other users as well as by companies without any direct interaction with the users. The advantage of accessing this kind of information is that it is created in a familiar environment that results in natural groups being formed. This makes it representative of the various segments' opinions.

In addition to posts by forum members, forum administrators allow nonmembers to post questions so that forums can be used to investigate specific questions game developers may have or to test product ideas, for example.

In the online community forums that we analyzed, the users provided direct feedback to the developers, suggesting what the game should do, or reacting to changes/improvements from previous versions. Thus, users provide direct feedback, but they also make indirect contributions, in that they report on their behaviors, emotions and opinions. For instance, one user reports that s/he was happy that his/her account for WoW had expired because the game had become boring. Hence, the use of online community discussions, and the analysis of user reactions to new ideas, etc., can be directly accessed and used as part of the IB decision-making process.

However, online communities lack clear organization, and this will become more important as they grow. If companies want to use the content provided by online communities, they need to find a way to extract the relevant information. Forum threads and content are not always linked and the challenge of identifying fruitful discussion threads and user contributions could make it difficult to conduct useful analysis on specific topics.

The analysis of online communities offers fascinating avenues for future research. Firms may consider collecting specific information about products and services that are under development and testing them by offering advance access to specific community user groups. In the MMORPG online community context, for instance, a key question may be the appeal of item-based versus subscriptionbased business models in new markets, such as Central and Eastern Europe (CEE).

One means of reaching online communities and their members is voice over IP (VoIP) software, such as Ventrilo or Teamspeak, and another is videoconferencing tools such as Skype. These offer verbal means of communication and are suitable for conducting online focus group discussions. MMORPG players already use Ventrilo and Teamspeak to communicate. The main advantage of using VoIP software is that primary data may be collected in a direct contact situation, via an online situation that people are already used to. However, contrary to existing online communities in forums, online focus group discussions seem to be difficult to set up due to the ethical and legal sensitivity of the topics and the impersonality and low trustworthiness of "virtual contact persons" from the players' side.

From a theoretical perspective, online communities offer an opportunity to study network-level innovation and extend the thinking of IB theory outside the 
firm as the central unit of analysis. Using this perspective, the notion of resource externalization (Lew and Sinkovics 2012) can be applied to understand new practices of innovation in IB.

\section{References}

Anderson, W. T., Challagalla, G. N., \& McFarland, R. G. (1999). Anatomy of exchange. Journal of Marketing Theory and Practice, 7(4), 8-19.

Andrews, D., Preece, J., \& Turoff, M. (2002). A conceptual framework for demographic groups resistant to on-line community interaction. International Journal of Electronic Commerce, 6(3), 9-24. doi:10.1109/HICSS.2001.927044.

Armstrong, A., \& John Hagel, I. I. I. (1996). The real value of on-line communities. Harvard Business Review, 74(3), 134-141.

Bagozzi, R. P., \& Dholakia, U. M. (2006). Antecedents and purchase consequences of customer participation in small group brand communities. International Journal of Research in Marketing, 23(1), 45-61. doi:10.1016/j.ijresmar.2006.01.005.

Balasubramanian, S., \& Mahajan, V. (2001). The economic leverage of the virtual community. International Journal of Electronic Commerce, 5(3), 103-138.

Basu, A., Mazumdar, T., \& Raj, S. P. (2003). Indirect network externality effects on product attributes. Marketing Science, 22(2), 209-221. doi:10.1287/mksc.22.2.209.16037.

Beckmann, SC., \& Langer, R. (2007). Netnographie. In R. Buber, H. H. Holzmüller (Eds.), Qualitative marktforschung - theorie, methode, analyse (pp. 219-228). Wiesbaden: Gabler Verlag. doi: 10.1007/978-3-8349-9258-1_57.

Blanchard, A. L. (2008). Testing a model of sense of virtual community. Computers in Human Behavior, 24(5), 2107-2123. doi:10.1016/j.chb.2007.10.002.

Brodie, L. M. (2009). Eproblem-based learning: Problem-based learning using virtual teams. European Journal of Engineering Education, 34(6), 497-509. doi:10.1080/03043790902943868.

Brown, J., Broderick, A. J., \& Lee, N. (2007). Word of mouth communication within online communities: conceptualizing the online social network. Journal of Interactive Marketing, 21(3), 2-20. doi:10.1002/dir.20082.

Business Insights. (2011). The video gaming industry outlook: online gaming market analysis. London: Business Insights Ltd.

Carrington, P. J., Scott, J., \& Wasserman, S. (2005). Models and methods in social network analysis. Cambridge: Cambridge University Press.

Casaló, L. V., Flavián, C., \& Guinalíu, M. (2008). Fundaments of trust management in the development of virtual communities. Management Research News, 31(5), 324-338.

Casaló, L. V., Flavián, C., \& Guinalíu, M. (2010). Relationship quality, community promotion and brand loyalty in virtual communities: evidence from free software communities. International Journal of Information Management, 30(4), 357-367. doi:10.1016/j.ijinfomgt. 2010.01.004.

Chan, K. W., \& Li, S. Y. (2010). Understanding consumer-to-consumer interactions in virtual communities: the salience of reciprocity. Journal of Business Research, 63(9-10), 1033-1040. doi:10.1016/j.jbusres.2008.08.009.

Chen, C. J., \& Hung, S. W. (2010). To give or to receive? Factors influencing members' knowledge sharing and community promotion in professional virtual communities. Information \& Management, 47(4), 226-236. doi:10.1016/j.im.2010.03.001.

Ciaramitaro, B. L. (2011). Virtual worlds and e-commerce technologies and applications for building customer relationships. Hershey, PA: Business Science Reference. 
Clemons, EK., Barnett, S., Appadurai, A. (2007). The future of advertising and the value of social network websites: Some preliminary examinations. In Proceedings of the ninth international conference on Electronic commerce (ICEC 2007). Minneapolis, MN, USA: ACM.

Cropanzano, R., \& Mitchell, Marie S. (2005). Social exchange theory: an interdisciplinary review. Journal of Management, 31(6), 874-900. doi:10.1177/0149206305279602.

de la Torre, J., \& Moxon, R. W. (2001). Introduction to the symposium e-commerce and global business: the impact of the information and communication technology revolution on the conduct of international business. Journal of International Business Studies, 32(4), 617-639. doi:10.1057/palgrave.jibs.8490988.

Dholakia, U. M., Bagozzi, R. P., \& Pearo, L. K. (2004). A social influence model of consumer participation in network- and small-group-based virtual communities. International Journal of Research in Marketing, 21(3), 241-263. doi:10.1016/j.ijresmar.2003.12.004.

Emerson, R. M. (1976). Social exchange theory. Annual Review of Sociology, 2, 335-362.

Evanschitzky, H., Eisend, M., Calantone, R. J., \& Jiang, Yuanyuan. (2012). Success factors of product innovation: an updated meta-analysis. Journal of Product Innovation Management, 29, 21-37. doi:10.1111/j.1540-5885.2012.00964.x.

Farrell, J., \& Saloner, G. (1985). Standardization, compatibility, and innovation. The Rand Journal of Economics, 16(1), 70-83. doi:10.2307/2555589.

Füller, J., Bartl, M., Ernst, H., \& Mühlbacher, H. (2006). Community based innovation: how to integrate members of virtual communities into new product development. Electronic Commerce Research, 6(1), 57-73. doi:10.1007/s10660-006-5988-7

Füller, J., Jawecki, G., \& Mühlbacher, H. (2007). Innovation creation by online basketball communities. Journal of Business Research, 60(1), 60-71. doi:10.1016/j.jbusres.2006.09.019

Gardiner, P. D., \& Ritchie, J. M. (1999). Project planning in a virtual world: Information management metamorphosis or technology going too far? International Journal of Information Management, 19(6), 485-494. doi:10.1016/s0268-4012(99)00044-4.

Ghauri, PN., \& Firth, R. (2009). The formalization of case study research in international business. der Markt, 48(1-2), 29-40. (DOI: 10.1007/s12642-009-0003-1).

Gu, B., Konana, P., Rajagopalan, B., \& Chen, H. W. M. (2007). Competition among virtual communities and user valuation: the case of investing-related communities. Information Systems Research, 18(1), 68-85. doi:10.1287/isre.1070.0114.

Guba, E. G., \& Lincoln, Y. S. (1989). Fourth generation evaluation. Newbury Park: Sage Publications.

Hemetsberger, A. (2002). Fostering cooperation on the internet: Social exchange processes in innovative virtual consumer communities. Advances in Consumer Research, 29(1), 354-356.

Hendaoui, A., Limayem, M., \& Thompson, C. W. (2008). 3d social virtual worlds: Research issues and challenges. Internet Computing, IEEE, 12(1), 88-92. doi:10.1109/mic.2008.1.

Hitzler, R. (2007). Ethnographie. In R. Buber, H. H. Holzmüller (Eds.), Qualitative marktforschung-theorie, methode, analyse, (pp. 207-218.)Wiesbaden: Gabler Verlag .doi: 10.1007/ 978-3-8349-9258-1_57).

Hof, R. D. (2005). The power of us. Business Week, 3938, 74-82.

Holmqvist, M. (2004). Experiential learning processes of exploitation and exploration within and between organizations: An empirical study of product development. Organization Science, 15(1), 70-81. doi:10.1287/orsc.1030.0056.

Hsu, C. L., \& HP, L. (2007). Consumer behavior in online game communities: a motivational factor perspective. Computers in Human Behavior, 23(3), 1642-1659. doi:10.1016/j.chb. 2005.09.001.

Jang, H., Lorne, O., Ko, I., Koh, J., \& Kim, K. (2008). The influence of on-line brand community characteristics on community commitment and brand loyalty. International Journal of Electronic Commerce, 12(3), 57-80. doi:10.2753/JEC1086-4415120304.

Katz, M. L., \& Shapiro, C. (1986). Technology adoption in the presence of network externalities. Journal of Political Economy, 94(4), 822-841. doi:10.2307/1833204. 
Kietzmann, J. H., Hermkens, K., McCarthy, I. P., \& Silvestre, B. S. (2011). Social media? Get serious! Understanding the functional building blocks of social media. Business Horizons, 54(3), 241-251. doi:10.1016/j.bushor.2011.01.005.

Kim, H. W., Gupta, S., \& Koh, J. (2011). Investigating the intention to purchase digital items in social networking communities: a customer value perspective. Information \& Management, 48(6), 228-234. doi:10.1016/j.im.2011.05.004.

Kock, N. (2008). E-collaboration and e-commerce in virtual worlds: the potential of second life and world of warcraft. International Journal of e-Collaboration (IJeC), 4(3), 1-13. doi:10. 4018/jec.2008070101.

Kogut, B., \& Zander, U. (1993). Knowledge of the firm and the evolutionary theory of the multinational corporation. Journal of International Business Studies, 24(4), 625-645. doi:10.1057/palgrave.jibs.8490248.

Kollock, P., \& Smith, M. (1999). Communities in cyberspace. London: Routledge.

Kozinets, R. V. (1999). E-tribalized marketing? The strategic implications of virtual communities of consumption. European Management Journal, 17(3), 252-264. doi:10.1016/S02632373(99)00004-3.

Kozinets, R. V. (2002). The field behind the screen: Using netnography for marketing research in online communities. Journal of Marketing Research, 39(1), 61-72.

Kuckartz, U. (2007). Computergestützte analyse qualitativer daten. In R. Buber, H. H. Holzmüller (Eds.), Qualitative marktforschung — theorie, methode, analyse (pp. 713-730).Wiesbaden: Gabler Verlag. doi: 10.1007/978-3-8349-9258-1_57.

Leamer, E. E., \& Storper, M. (2001). The economic geography of the internet age. Journal of International Business Studies, 32(4), 641-665. doi:10.1057/palgrave.jibs.84909988.

Lee, Y., \& O'Connor, G. C. (2003). New product launch strategy for network effects products. Journal of the Academy of Marketing Science, 31(3), 241-255. doi:10.1177/0092070303031003003.

Lew, Y. K., \& Sinkovics, R. R. (2012). Practices of innovation in mobile computing alliances. In S. Harris, O. Kuivalainen, and V. Stoyanova (Eds.), International business—new challenges, new forms, new perspectives (pp. 242-261). Houndmills: Palgrave MacMillan. doi: 10.1057/ 9781137007742).

Lew, Y. K., \& Sinkovics, R. R. (2013). Crossing borders and industry sectors: behavioral governance in strategic alliances and product innovation for competitive advantage. Long Range Planning, 46(1-2), 13-38. doi: 10.1016/j.lrp.2012.09.006.

Mahr, D., \& Lievens, A. (2012). Virtual lead user communities: Drivers of knowledge creation for innovation. Research Policy, 41(1), 167-177. doi:10.1016/j.respol.2011.08.006.

Mandiberg, M. (2012). The social media reader. New York: New York University Press.

Marschan-Piekkari, R., \& Welch, C. (Eds.). (2004). Handbook of qualitative research methods for international business. Cheltenham: Edward Elgar.

Molina-Castillo, F. J., Jimenez-Jimenez, D., \& Munuera-Aleman, J. L. (2011a). Product competence exploitation and exploration strategies: The impact on new product performance through quality and innovativeness. Industrial Marketing Management, 40(7), 1172-1182. doi:10.1016/j.indmarman.2010.12.017.

Molina-Castillo, F. J., Munuera-Alemán, J. L., \& Calantone, R. J. (2011b). Product quality and new product performance: the role of network externalities and switching costs. Journal of Product Innovation Management, 28(6), 915-929. doi:10.1111/j.1540-5885.2011.00847.x.

Muniz, A. M, Jr, \& O'Guinn, T. C. (2001). Brand community. Journal of Consumer Research, 27(4), 412-432. doi:10.1086/319618

Nambisan, P., \& Watt, J. H. (2011). Managing customer experiences in online product communities. Journal of Business Research, 64(8), 889-895. doi:10.1016/j.jbusres.2010.09. 006.

Norsworthy, R., \& Lee, Y. (1998). Returns to scale and network effects. Troy: Lally School of Management and Technology.

Okoli, C., \& Pawlowski, S. D. (2004). The delphi method as a research tool: An example, design considerations and applications. Information \& Management, 42(1), 15-29. doi:10.1016/ j.im.2003.11.002. 
Penz, E., \& Sinkovics, R. R. (2005). Formalisierung qualitativer internationaler marketingforschung—grundsätze und anwendungsfall. In H. H. Holzmüller, A. Schuh (Eds.), Innovationen im sektoralen Marketing_Festschrift zum 60. Geburtstag von Fritz Scheuch (pp. 235-256). Heidelberg: Physica Verlag.

Perks, H., Gruber, T., \& Edvardsson, B. (2012). Co-creation in radical service innovation: a systematic analysis of microlevel processes. Journal of Product Innovation Management, 29(6), 935-951. doi:10.1111/j.1540-5885.2012.00971.x.

Preece, J. (2000). Online communities: supporting sociability, designing usability. New York: John Wiley.

Rheingold, H. (1993). The virtual community: homesteading on the electronic frontier. London: Secker and Warburg.

Richards, L. (2005). Handling qualitative data-a practical guide. London: Sage Publications.

Rowe, G., \& Wright, G. (1999). The delphi technique as a forecasting tool: Issues and analysis. International Journal of Forecasting, 15(4), 353-375. doi:10.1016/S0169-2070(99)00018-7.

Scarpi, D. (2010). Does size matter? An examination of small and large web-based brand communities. Journal of Interactive Marketing, 24(1), 14-21. doi:10.1016/j.intmar.2009.10. 002.

Sinkovics, R. R., \& Alfoldi, E. A. (2012). Progressive focusing and trustworthiness in qualitative research: The enabling role of computer-assisted qualitative data analysis software (CAQDAS). Management International Review, 52(6), 817-845. doi:10.1007/s11575-0120140-5.

Sinkovics, R. R., Penz, E., \& Ghauri, P. N. (2005). Analysing textual data in international marketing research. Qualitative Market Research: An International Journal, 8(1), 9-38. doi:10.1108/13522750510575426.

Sinkovics, R. R., Penz, E., \& Ghauri, P. N. (2008). Enhancing the trustworthiness of qualitative research in international business. Management International Review, 48(6), 689-714. doi:10.1007/s11575-008-0103-z.

Sinkovics, R., Penz, E., Castillo, F. J. M. (2009). Qualitative analyse von online communities für neuproduktentscheidungen. der Markt, 48(1), 61-72. doi: 10.1007/s12642-009-0004-0.

Song, P., Zhang, C., Yunjie, X., \& Huang, L. (2010). Brand extension of online technology products: evidence from search engine to virtual communities and online news. Decision Support Systems, 49(1), 91-99. doi:10.1016/j.dss.2010.01.005.

Spaulding, T. J. (2010). How can virtual communities create value for business? Electronic Commerce Research and Applications, 9(1), 38-49. doi:10.1016/j.elerap.2009.07.004.

Srinivasan, R., Lilien, G. L., \& Rangaswamy, A. (2004). First in, first out? The effects of network externalities on pioneer survival. Journal of Marketing, 68(1), 41-58. doi:10.2307/30161974.

Strauss, A., \& Corbin, J. (1994). Grounded theory methodology—an overview. In N. K. Denzin, Y. S. Lincoln (Eds.), Handbook of qualitative research (pp. 273-285), Thousand Oaks: Sage Publications.

Strauss, A. L., \& Corbin, J. M. (1998). Basics of qualitative research: Grounded theory procedures and techniques. Thousand Oaks: Sage Publications.

Sun, Y., Fang, Y., \& Lim, K. H. (2012). Understanding sustained participation in transactional virtual communities. Decision Support Systems, 53(1), 12-22. doi:10.1016/j.dss.2011.10.006.

Tsai, H. T., \& Pai, P. (2012). Positive and negative aspects of online community cultivation: Implications for online stores' relationship management. Information \& Management, 49(2), 111-117. doi:10.1016/j.im.2011.11.002.

Turkle, S. (2011). Alone together: why we expect more from technology and less from each other. New York: Basic Books.

von Hippel, E., \& von Krogh, G. (2003). Open source software and the "private-collective" innovation model: Issues for organization science. Organization Science, 14(2), 209-223.

Wang, J. F. (2010). E-commerce communities as knowledge bases for firms. Electronic Commerce Research and Applications, 9(4), 335-345. doi:10.1016/j.elerap.2009.11.005.

Wasko, M. M., \& Faraj, S. (2005). Why should i share? Examining social capital and knowledge contribution in electronic networks of practice. MIS Quarterly, 29(1), 35-57. 
Wasserman, S., \& Faust, K. (1994). Social network analysis: methods and applications. Cambridge: Cambridge University Press.

Winkler, K., \& Mandl, H. (2004). Virtuelle communities-Kennzeichen, Gestaltungsprinzipien und Wissensmanagement-prozesse. In Forschungsbericht Nr. 166. München: LudwigMaximilians-Universität München.

Wu, S. C., \& Fang, W. C. (2010). The effect of consumer-to-consumer interactions on idea generation in virtual brand community relationships. Technovation, 30(11-12), 570-581. doi: 10.1016/j.technovation.2010.07.005.

Yamin, M., \& Sinkovics, R. R. (2006). Online internationalisation, psychic distance reduction and the virtuality trap. International Business Review, 15(4), 339-360. doi:10.1016/j.ibusrev. 2006.03.002.

Zhou, Z., Zhang, Q., Chenting, S., \& Zhou, N. (2012). How do brand communities generate brand relationships? Intermediate mechanisms. Journal of Business Research, 65(7), 890-895. doi:10.1016/j.jbusres.2011.06.034. 